\title{
The first report of RPSA polymorphisms, also called 37/67 kDa LRP/LR gene, in sporadic Creutzfeldt-Jakob disease (CJD)
}

Jisuk Yun ${ }^{1}$, Hyoung-Tae Jin ${ }^{1}$, Yun-Jung Lee ${ }^{1}$, Eun-Kyoung Choi ${ }^{1}$, Richard I Carp², Byung-Hoon Jeong ${ }^{1 *}$ and Yong-Sun Kim ${ }^{1 *}$

\begin{abstract}
Background: Although polymorphisms of PRNP, the gene encoding prion protein, are known as a determinant affecting prion disease susceptibility, other genes also influence prion incubation time. This finding offers the opportunity to identify other genetic or environmental factor (s) modulating susceptibility to prion disease. Ribosomal protein SA (RPSA), also called $37 \mathrm{kDa}$ laminin receptor precursor (LRP)/67 kDa laminin receptor (LR), acts as a receptor for laminin, viruses and prion proteins. The binding/internalization of prion protein is dependent for LRP/LR.

Methods: To identify other susceptibility genes involved in prion disease, we performed genetic analysis of RPSA. For this case-control study, we included 180 sporadic Creutzfeldt-Jakob disease (CJD) patients and 189 healthy Koreans. We investigated genotype and allele frequencies of polymorphism on RPSA by direct sequencing or restriction fragment length polymorphism (RFLP) analysis.

Results: We observed four single nucleotide polymorphisms (SNPs), including -8T>C (rs1803893) in the 5'untranslated region (UTR) of exon 2, 134-32C C T (rs3772138) in the intron, 519G $>$ A (rs2269350) in the intron and $793+58 \mathrm{C}>\mathrm{T}$ (rs2723) in the intron on the RPSA. The 519G $>$ A (at codon 173) is located in the direct PrP binding site. The genotypes and allele frequencies of the RPSA polymorphisms showed no significant differences between the controls and sporadic CJD patients.

Conclusion: These results suggest that these RPSA polymorphisms have no direct influence on the susceptibility to sporadic CJD. This was the first genetic association study of the polymorphisms of RPSA gene with sporadic CJD.
\end{abstract}

\section{Background}

Human prion diseases are fatal transmissible neurodegenerative disorders with accumulation of an abnormal infectious isoform $\left(\mathrm{PrP}^{\mathrm{Sc}}\right)$ in central nervous system and spleen. Approximately $85 \%$ of Creutzfeldt-Jakob disease (CJD) is sporadic CJD that differs from generically linked variant CJD in its relatively late age incidence and short duration of illness $[1,2]$. It is known that the conformational conversion of naturally expressed cellular prion protein $\left(\mathrm{PrP}^{\mathrm{C}}\right)$ to $\mathrm{PrP}^{\mathrm{Sc}}$ is the key event in the pathogenesis of prion disease.

\footnotetext{
* Correspondence: bhjeong@hallym.ac.kr; yskim@hallym.ac.kr ${ }^{1}$ Ilsong Institute of Life Science, Hallym University, 1605-4 Gwanyang-dong Dongan-gu, Anyang, Gyeonggi-Do 431-060, Republic of Korea Full list of author information is available at the end of the article
}

It is known that homozygous codon 129 of human prion protein gene (PRNP) increases the risk of CJD. Although about $40 \%$ of the British and about $95 \%$ of the Korean have this genotype, the incidences of sporadic CJD are similar [3-5]. This epidemiological data suggests that allelic frequencies of PRNP codon 129 are unlikely to be the sole genetic factor for sporadic CJD incidence [3]. Inbred mouse lines encoding the same PRNP genotype differed significantly in incubation time [6,7]. In addition, new quantitative trait loci (QTL) that affect prion disease incubation time have been detected [7-9]. These results make it possible to study other candidate loci and factors that play a role in the onset time of prion disease.

The $37 \mathrm{kDa}$ laminin receptor precursor (LRP)/67 kDa laminin receptor (LR) is a multifunctional protein which

\section{Biomed Central}

(c) 2011 Yun et al; licensee BioMed Central Ltd. This is an Open Access article distributed under the terms of the Creative Commons Attribution License (http://creativecommons.org/licenses/by/2.0), which permits unrestricted use, distribution, and reproduction in any medium, provided the original work is properly cited. 
acts as a receptor for laminin and is involved in organization of basement membrane [10]. LRP forms its mature LR by unknown mechanism involving posttranslational fatty acid acylation [11,12]. LRP exists on the cell surface and LR is embedded in cell membrane [11]. The open reading frame (ORF) of the human LRP/ LR gene, also called ribosomal protein SA (RPSA), is 888 bp in length, codes a protein of 295 amino acids and is found on chromosome $3 \mathrm{p} 22.2$. The amino acid sequence of RPSA shares high homology in mammals [10]. LRP/LR also acts as a receptor for many components; carbohydrates, elastin, green tea catching epigallocatechin-3-gallate (EGCG), various viruses, bacteria and prion protein $[11,12]$. LRP/LR can be a factor in pathological processes. In cancer, LRP/LR is upregulated and its overexpression is associated with tumor cell metastasis and attack $[11,12]$. In prion disease, LRP/LR acts as a receptor for $\mathrm{PrP}^{\mathrm{Sc}}$ as well as a receptor or co-receptor for $\operatorname{PrP}^{\mathrm{c}}$ [11-15]. $\mathrm{PrP}^{\mathrm{c}}$ is co-localized with $\mathrm{LRP} / \mathrm{LR}$ on the surface of mammalian cells [13]. Enhanced LRP/LR level was only found in systems converting $\operatorname{PrP}^{\mathrm{c}}$ to $\operatorname{PrP}^{\mathrm{Sc}}$ and in organs accumulating $\operatorname{PrP}^{\mathrm{Sc}}$ such as brain, spleen and pancreas in scrapie-infected mice and hamsters [15]. Bovine prion protein $\left(\mathrm{PrP}^{\mathrm{BSE}}\right)$ after oral infection is internalized by human enterocytes via a specific LRP/LRdependent process [16]. LRP/LR is essential for the propagation and accumulation of $\mathrm{PrP}^{\mathrm{Sc}}$ in scrapieinfected cells, and its expression is related to the degree of $\mathrm{PrP}^{\mathrm{Sc}}$ propagation $[17,18]$. Therefore, it is possible that PrP-LRP-LR interaction is related to pathogenesis of prion disease. LRP/LR also has potential as an alternative therapeutic strategy that aims at LRP interactions $[19,20]$. Recent studies showed that inactivation of LRP/LR interferes with either $\mathrm{PrP}^{\mathrm{Sc}}$ propagation or $\mathrm{PrP}^{\mathrm{Sc}}$ accumulation, leading to a prolonged pre-clinical phase and incubation times in scrapie-infected mice $[21,22]$. Catechin EGCG, a component in green tea, represents antiallergic, anti-tumor and anti-obesity actions via binding to LRP/LR [23-25]. EGCG treatment interferes with the formation of $\mathrm{PrP}^{\mathrm{Sc}}$ in scrapie-infected cells and with the stress-protective effect of $\operatorname{PrP}^{\mathrm{C}}$ in uninfected cells [26].

Although PrP-LRP-LR interaction is important for prion disease, a relationship between RPSA polymorphism and prion disease has not been reported. Therefore, we investigated polymorphisms of human RPSA, and studied whether these polymorphisms are related to susceptibility to sporadic CJD.

\section{Methods}

\section{Subjects}

This study included 180 sporadic CID patients (93 male and 87 female; mean age at disease onset $61.4 \pm 12.0$ ) and 189 healthy controls (89 male and 100 female; mean age at blood collection $71.7 \pm 8.9)$ who were all unrelated and from an ethnically homogenous Korean population (Table 1). Blood samples were collected from May 1996 to April 2006.

The clinical criteria for sporadic CJD patients were established according to the WHO diagnostic criteria for definite or probable CJD [27]. In brief, definite CJDs were neuropathologically confirmed and/or immunochemically detected by presence of $\operatorname{PrP}^{\mathrm{Sc}}$ in the brain. Probable CJDs were diagnosed by presence of progressive dementia, a typical electroencephalography (EEG), and/or a positive 14-3-3 protein in CSF and a clinical duration leading to death in $<2$ years and at least two of the following: myoclonus, visual or cerebellar disturbance, pyramidal, extrapyramidal dysfunction, akinetic mutism. Patients with mutation in the PRNP were excluded from this study. 12 definite sporadic CJD and 168 probable sporadic CJD cases were enrolled in our study.

All healthy control subjects participated voluntarily during routine checkups at the Chuncheon Sacred Heart Hospital and Hallym University Sacred Heart Hospital. The purpose of the study was carefully explained to all study participants or their representatives and their informed consents were obtained. The study complied with the Guidelines for Genome/Genetic Research issued by the Korean government and was approved by the Ethical Committee of Hallym University Sacred Heart Hospital, Anyang, Korea.

\section{Genetic analysis}

Whole blood samples were drawn into ethylenediaminetetraacetate (EDTA)-treated tubes and were kept frozen at $-70^{\circ} \mathrm{C}$ until analysis. Genomic DNA was extracted from whole blood using the QIAamp ${ }^{\circledR}$ DNA blood Mini Kit (QIAGEN, Valencia, CA, USA) according to the manufacturer's instruction. For the screening polymorphisms in the LRP/LR, polymerase chain reaction (PCR) was performed with forward primer and reverse primer (Table 2). A $50 \mu \mathrm{L}$ reaction mixture containing $10 \mu \mathrm{L}$ of genomic DNA, $1 \mu \mathrm{L}$ each of forward and reverse primers, $4 \mu \mathrm{L}$ of $2.5 \mathrm{mM}$ dNTP mixture, $5 \mu \mathrm{L}$ of 10X Taq DNA polymerase buffer (Promega, Madison, WI., USA), $0.5 \mu \mathrm{L}$ of 2.5 units Taq DNA polymerase (Promega, Madison, WI., USA) and $23.5 \mu \mathrm{L}$ of sterile deionized water was placed in PTC-200 Peltier Thermal Cycler (MJ Research, Reno, NV, USA). PCR reactions were thermally cycled with an initial denaturation at $90^{\circ} \mathrm{C}$ for 3 minutes, followed by 35 cycles of $95^{\circ} \mathrm{C}$ for 30 seconds, $57^{\circ} \mathrm{C}$ for 30 seconds and $72^{\circ} \mathrm{C}$ for 1.5 minutes and then a final extension at $72^{\circ} \mathrm{C}$ for $4 \mathrm{~min}$ utes. Each PCR product was run on a $1 \%$ agarose gel stained with ethidium bromide (EtBr), and then was purified by QIAquick ${ }^{\circledR}$ Gel Extraction Kit (QIAGEN, Valencia, CA., USA). The PCR products were directly sequenced with an ABI 3730 Capillary Electrophoresis Sequencer (Applied Biosystems, Foster City, CA, USA). 
Table 1 General characteristics of healthy controls and sporadic CJD patients

\begin{tabular}{lccc}
\hline & $\begin{array}{c}\text { healthy controls } \\
(\mathbf{n}=\mathbf{1 8 9})\end{array}$ & $\begin{array}{c}\text { Sporadic CJD patients } \\
(\mathbf{n}=\mathbf{1 8 0})\end{array}$ & P-value \\
\hline Gender & & & \\
$\quad$ Male, $\mathrm{n}(\%)$ & $89(47.1 \%)$ & $93(51.7 \%)$ & 0.379 \\
$\quad$ Female, $\mathrm{n}(\%)$ & $100(52.9 \%)$ & $87(48.3 \%)$ & $<1.4 \pm 12.0$ \\
Mean age at disease onset (yrs) & - & - & $<.01$ \\
Mean age at blood collection (yrs) & $71.7 \pm 8.9$ & \\
\hline
\end{tabular}

Data are mean \pm S.D. or percentage

Alleles of RPSA 2, RPSA 4 and RPSA 5 were determined by PCR restriction fragment length polymorphism (RFLP). Restriction sites were searched using Webcutter $2.0 \mathrm{http} / / /$ rna.lundberg.gu.se/cutter2. Restriction digests (enzymes supplied by Fermentus) were performed in a $20 \mu \mathrm{L}$ reaction mixture containing $10 \mu \mathrm{L}$ of PCR reaction mixture, $2 \mu \mathrm{L}$ of $10 \times$ buffer $\mathrm{B}, 0.5 \mu \mathrm{L}$ of TasI and $7.5 \mu \mathrm{L}$ of sterile deionized water was digested at $65^{\circ} \mathrm{C}$ for 4 hours. Digested PCR products were electrophoresed on a 2\% agarose gel and visualized with $\mathrm{EtBr}$ staining under UV light.

\section{Statistical analysis}

Statistical data were carried out using Statistical Analysis Software (SAS), version 8.2 (SAS Institute Inc., Cary, NC., USA). The $\chi^{2}$ test was used to assess differences between categorical variables. Difference between the two groups regarding genotype frequencies were determined by Fisher's exact test, and comparisons of allele frequencies were assessed by $\chi^{2}$-test. Student's t-test was used to analyze differences between the normal population and sporadic CJD patients by age. Hardy-Weinberg Equilibrium test and haplotype analysis were performed by use of the SNPAnalyzer 1.2A http://snp.istech21.com/snpanalyzer/ 1.2A/. Linkage disequilibrium (LD) between paired polymorphisms was tested.

\section{Results}

To identify an association between RPSA polymorphisms and sporadic CJD, we screened nucleotide variations in RPSA using direct gene sequence or RFLP analysis. We observed four single nucleotide polymorphisms (SNPs), including $-8 \mathrm{~T}>\mathrm{C}(\mathrm{rs} 1803893)$ in the $5^{\prime}$ untranslated region (UTR) of exon 2, 134-32C $>\mathrm{T}$ (rs3772138) in the intron, 519G $>$ A (rs2269350) in exon 5 and $793+58 \mathrm{C}>\mathrm{T}(\mathrm{rs} 2723)$ in the intron. The genotype frequencies of all SNPs followed Hardy-Weinberg equilibrium except for RPSA $793+58 \mathrm{C}>\mathrm{T}$ in controls (data not shown).

We analyzed the extent of LD between the polymorphisms. Four SNPs identified in the RPSA were strongly linked together with $D^{\prime}$ values 0.94 - 1.00 (Table 3 ). Because four RPSA polymorphisms are in strong LD, we analyzed the genotype frequency of RPSA $5^{\prime}-\mathrm{UTR}-8 \mathrm{~T}>\mathrm{C}$ using direct sequencing, whereas frequencies of other genes were determined using RFLP analysis. As shown in Table 4, there was no significant difference in the genotype distribution of the RPSA polymorphisms between controls and sporadic CJD groups. Allele frequencies of RPSA polymorphisms also showed no differences between these two groups. In addition, the genetic variations of these polymorphisms were equally frequent by gender (data not shown).

As shown in Table 5, five different haplotypes exist in the RPSA polymorphisms: TCGT, CTAC, TCGC, CCGC and CTGT. Among the five haplotypes, the haplotype TCGT was observed more frequently (67\% for controls; $69 \%$ for sporadic CJD patients); the second major haplotype was CTAC (18\% for controls; $19 \%$ for sporadic CJD patients). The haplotype CTGT was less frequently

Table 2 PCR primers used to screen the RPSA

\begin{tabular}{|c|c|c|c|}
\hline Primer identity & Primer sequences & Nucleotide position & Product size \\
\hline RPSA 1 & $\begin{array}{l}\text { A: GAT GTG CGC TGT TCC GTA AT } \\
\text { B: TCA TGT TCA TGA CCC AAC CC }\end{array}$ & $1026-1601$ & $576 \mathrm{bp}$ \\
\hline RPSA 2 & $\begin{array}{l}\text { A: GGA AAG AGT GGC AGA AAG CC } \\
\text { B: TGC TGG GAT TAC AGG CGT AG }\end{array}$ & $1866-2431$ & 566 bp \\
\hline RPSA 3 & $\begin{array}{l}\text { A: CCA GTG CCC AGA AGT GCT TA } \\
\text { B: TTC ATC GGC CAG TCA GTA GC }\end{array}$ & $4252-4681$ & $430 \mathrm{bp}$ \\
\hline RPSA 4 & $\begin{array}{l}\text { A: GCT TGC TGT TTG GGT TTG AC } \\
\text { B: TTC CTT ACC CCA CTC CCA AC }\end{array}$ & $5171-5799$ & $629 \mathrm{bp}$ \\
\hline RPSA 5 & $\begin{array}{l}\text { A: AAG CAA AAC TTG TCA GTC CCT G } \\
\text { B: CAA CCA TाT TTC CAT GCT GC }\end{array}$ & $5421-5990$ & $570 \mathrm{bp}$ \\
\hline
\end{tabular}

' $A$ ' indicates the forward primer, and ' $B$ ' indicates the reverse primer. 
Table $3 D^{\prime}$ Values for Linkage Disequilibrium (LD) between RPSA polymorphisms

\begin{tabular}{|c|c|c|c|c|}
\hline & $5^{\prime}$-UTR $-8 \mathrm{~T}>C$ & $134-32 \mathrm{C}>\mathrm{T}$ & $519 G>A$ & $793+58 C>T$ \\
\hline $5^{\prime}-$ UTR $-8 \mathrm{~T}>\mathrm{C}$ & - & 1.00 & 1.00 & 0.94 \\
\hline $134-32 C>T$ & - & - & 1.00 & 0.96 \\
\hline $519 G>A$ & - & - & - & 1.00 \\
\hline $793+58 C>T$ & - & - & - & - \\
\hline
\end{tabular}

observed in both controls and sporadic CJD patients (1\% for both controls and sporadic CJD patients). Analysis of the haplotype frequencies of RPSA polymorphisms showed no significance between controls and sporadic CJD patients.

In order to identify whether the RPSA polymorphism affects susceptibility to sporadic CJD, we tested for LD with PRNP codon 129 polymorphism. Because four $R P S A$ polymorphisms have strong $\mathrm{LD}$, we only tested RPSA 1 polymorphism. The RPSA 5'-UTR - 8T >C polymorphism is in low LD with both PRNP codon 129 polymorphism and 219 polymorphism $\left(D^{\prime}=0.497\right.$ and $D^{\prime}=0.110$, respectively).

To identify the combined effects of RPSA and PRNP on susceptibility to prion disease, RPSA 5'-UTR $-8 \mathrm{~T}>\mathrm{C}$ genotype data was stratified with $P R N P$ codon 129 and with codon 219 genotypes (Table 6). We found no significant differences in the genotype and allele frequencies of RPSA 5'-UTR - $8 \mathrm{~T}>\mathrm{C}$ polymorphism according to the PRNP codon 129 status. Similar results were seen when stratified with PRNP codon 219.

\section{Discussion}

In order to find association of RPSA with sporadic CJD, we screened sequence of the RPSA in all available samples of sporadic CJD patients from Korean populations and investigated SNPs in the LRP/LR gene. In this study, we identified four polymorphisms including $519 \mathrm{G}>\mathrm{A}$ (at codon 173 ) in the coding region and three SNPs located in 5'-
UTR and intron on the RPSA. By two-hybrid system in the yeast and cell-binding assay, two PrP-LRP-LR interaction domains on PRNP were identified: a direct binding domain amino acids 144-179, termed PrPLRPbd1 and an indirect heparin sulfate proteoglycan (HSPG)-dependent LRP binding domain amino acids 53-93, termed PrPLRPbd2 [28]. On RPSA, the direct PrP binding site is amino acids 161-180 and the heparin sulfate-dependent PrP-binding site is amino acids 205-229 [29]. The RPSA polymorphism at codon 173 is a synonymous SNP, which encodes leucine, and does not lead to substitution of amino acid. Nevertheless, it remains of interest, because the polymorphism at codon 173 is located in the direct PrP binding domain. Similar to our study, ovine RPSA polymorphisms in the regions related to PrP-LRP-LR interaction did not lead to a change in amino acid sequence [30]. Although the effects of this SNP on LRP/ LR biology or prion biology are unknown, it is possible that the differences in combinations of amino acids may modify its specificity with other proteins affecting PrPLRP-LR interaction, strengthening or weakening the species barrier [30]. The RPSA amino acid sequences associated with resistance barrier to scrapie infection have been identified at positions 241, 272 and 291 in goat [31], and at positions 241, 271 and 290 in sheep [30]. SNPs in UTR are known to have an effect on the expression or stability of genes. It is possible that the 5'-UTR $-8 \mathrm{~T}>\mathrm{C}$ polymorphism may be responsible for genetic susceptibility to sporadic CJD.

In addition to differences in LRP/LR amino acid sequence, which affects the interaction with $\operatorname{PrP}^{\mathrm{Sc}}$, differences in the production/expression of LRP/LR bioavailability at the cell surface and particular conformations might be regional leading to cellular differences in binding/accumulation of prion proteins; the result of these differences could lead to variable response to scrapie infection [30,32]. LRP is relatively abundant in developing brain tissue, and its expression is limited to a few

Table 4 Genotype and allele frequencies of RPSA polymorphisms in controls and sporadic CJD patients

\begin{tabular}{|c|c|c|c|c|c|c|c|c|}
\hline & \multicolumn{2}{|c|}{$5^{\prime}-U T R-8 T>C$} & \multicolumn{2}{|c|}{$134-32 C>T$} & \multicolumn{2}{|c|}{$519 G>A$} & \multicolumn{2}{|c|}{$793+58 C>T$} \\
\hline & $\begin{array}{l}\text { Controls } \\
(n=189)\end{array}$ & $\begin{array}{l}\text { Sporadic CJDs } \\
\quad(n=180)\end{array}$ & $\begin{array}{l}\text { Controls } \\
(n=50)\end{array}$ & $\begin{array}{l}\text { Sporadic CJDs } \\
\quad(n=50)\end{array}$ & $\begin{array}{l}\text { Controls } \\
(n=50)\end{array}$ & $\begin{array}{l}\text { Sporadic CJDs } \\
\quad(n=50)\end{array}$ & $\begin{array}{l}\text { Controls } \\
(\mathrm{n}=50)\end{array}$ & $\begin{array}{l}\text { Sporadic CJDs } \\
\quad(n=50)\end{array}$ \\
\hline \multicolumn{9}{|l|}{ Genotype } \\
\hline $1 / 1$ & $91(48.2 \%)$ & 87 (48.3\%) & 33 (66.0\%) & $33(66.0 \%)$ & 34 (68.0\%) & 33 (66.0\%) & $28(56.0 \%)$ & 24 (48.0\%) \\
\hline $1 / 2$ & 77 (40.7\%) & 78 (43.3\%) & 15 (30.0\%) & 15 (30.0\%) & $14(28.0 \%)$ & 15 (30.0\%) & $12(24.0 \%)$ & $22(44.0 \%)$ \\
\hline $2 / 2$ & $21(11.1 \%)$ & 15 (8.4\%) & $2(4.0 \%)$ & $2(4.0 \%)$ & $2(4.0 \%)$ & $2(4.0 \%)$ & $10(20.0 \%)$ & $4(8.0 \%)$ \\
\hline$P$-value & \multicolumn{2}{|r|}{0.646} & \multicolumn{2}{|r|}{1.000} & \multicolumn{2}{|r|}{1.000} & \multicolumn{2}{|r|}{0.058} \\
\hline \multicolumn{9}{|l|}{ Allele } \\
\hline 1 & $279(0.70)$ & $252(0.70)$ & $81(0.81)$ & $81(0.81)$ & $82(0.82)$ & $81(0.81)$ & $68(0.68)$ & $70(0.70)$ \\
\hline 2 & $119(0.30)$ & $108(0.30)$ & $19(0.19)$ & $19(0.19)$ & $18(0.18)$ & $19(0.19)$ & $32(0.32)$ & $30(0.30)$ \\
\hline$P$-value & \multicolumn{2}{|c|}{0.976} & \multicolumn{2}{|c|}{1.000} & \multicolumn{2}{|c|}{0.856} & \multicolumn{2}{|r|}{0.760} \\
\hline
\end{tabular}

For columns ' 1 ' refers to the more common genotype or allele and ' 2 ' to the less common genotype or allele of each polymorphism. 
Table 5 Haplotype frequency of RPSA polymorphisms in controls and sporadic CJD patients

\begin{tabular}{cccc}
\hline Haplotype & $\begin{array}{c}\text { Controls } \\
(\mathbf{n}=\mathbf{5 0})\end{array}$ & $\begin{array}{c}\text { Sporadic CJDs } \\
(\mathbf{n}=\mathbf{5 0})\end{array}$ & $\boldsymbol{P}$-value \\
\hline TCGT & $67.0 \%$ & $68.9 \%$ & - \\
CTAC & $18.0 \%$ & $19.0 \%$ & 0.943 \\
TCGC & $9.0 \%$ & $6.1 \%$ & 0.574 \\
CCGC & $5.0 \%$ & $4.9 \%$ & 0.714 \\
CTGT & $1.0 \%$ & $1.1 \%$ & 0.983 \\
\hline
\end{tabular}

neurons in cortex known to be especially sensitive to abnormal prion accumulation, and these cells rapidly degenerate during the early stages of CJD $[32,33]$. LR is expressed in most adult neurons, and a subset of glial cells and astrocytes, which can accumulate $\mathrm{PrP}^{\mathrm{Sc}}$ in scrapie-infected hamsters [32]. $\operatorname{PrP}^{\mathrm{C}}$-LRP-LR interaction, related to prion protein binding/accumulation, may take place at the cell soma and apical dendrites [32]. LRP is localized in the cytoplasm and in the nucleus, and LR can be present as a laminin-binding protein on the cell surface or in a free form in the extracellular matrix $[11,30]$.

As shown in Table 4, although we found no significant difference in the genotype and allele frequencies of the RPSA polymorphisms between controls and sporadic CJD groups, RPSA $793+58 \mathrm{C}>\mathrm{T}$ showed a tendency to lower frequency of heterozygotes in sporadic CJD patients than those of controls $(P=0.058)$. Since the number of RPSA $793+58 C>T$ was much smaller $(\mathrm{n}=50$ for controls, $\mathrm{n}=50$ for sporadic CJD patients), further study on whether this result relates to our small sample sizes is required. In our study, the genotype and allele frequencies of RPSA polymorphisms were not influenced by gender. Lloyd et al. [7] and Stephenson et al. [8] reported that prion disease incubation time is not affected by sex. In contrast, the studies of Moreno et al. [9] showed that the survival time of female mice is shorter than those of male mice. The source of this sex effect could be hormonal factors, body size, fat composition, appetite and so on, acting at the end of the survival time [9].

One major haplotype (TCGT) is present in both controls and sporadic CJD patients with frequencies of $67-$ 69\% (Table 5). The additional four haplotypes were not significantly different in the two populations.

Some SNPs may act through LD with other mutations, even if it may not have direct influence on sporadic CJD susceptibility. From this point of view, we tested for LD between RPSA polymorphisms and PRNP codon 129 . We found that RPSA polymorphisms had no effect on the susceptibility of $129 \mathrm{MM}$ individuals to sporadic CJD. To fully elucidate the association of the RPSA polymorphisms with sporadic CJD susceptibility, further studies are required using various populations because different linkage patterns can occur in different populations.

The PRNP associated resistance/susceptibility for prion disease is likely to coexist with other genes modulating its effect [30]. In previous studies, we found that

Table 6 Genotype and allele frequencies of RPSA 5-UTR -8T>C polymorphism according to the PRNP codon 129 or 219 status

\begin{tabular}{|c|c|c|c|c|c|c|c|c|}
\hline \multirow[t]{2}{*}{ PRNP 129} & \multicolumn{3}{|c|}{ Healthy controls ( $n=189$ ) } & \multicolumn{3}{|c|}{ Sporadic CJD patients $(n=180)$} & \multirow[t]{2}{*}{$P$-value ${ }^{1}$} & \multirow[t]{2}{*}{$P$-value } \\
\hline & $\mathrm{MM}(\mathrm{n}=180)$ & $M V(n=9)$ & $V V(n=0)$ & $\mathrm{MM}(\mathrm{n}=180)$ & $M V(n=0)$ & $V V(n=0)$ & & \\
\hline \multicolumn{9}{|c|}{ Genotype frequency, n (\%) } \\
\hline$\Pi$ & $84(46.7)$ & $7(7.8)$ & - & $87(48.3)$ & - & - & & \\
\hline $\mathrm{TC}$ & $75(41.7)$ & $2(2.2)$ & - & $78(43.3)$ & - & - & 0.233 & 0.570 \\
\hline $\mathrm{CC}$ & $21(11.6)$ & $0(0)$ & - & $15(8.3)$ & - & - & & \\
\hline \multicolumn{9}{|c|}{ Allele frequency } \\
\hline $\mathrm{T}$ & 0.68 & 0.89 & - & 0.70 & - & - & 0.057 & 0.469 \\
\hline C & 0.32 & 0.11 & - & 0.30 & - & - & & \\
\hline \multirow[t]{2}{*}{ PRNP 219} & \multicolumn{3}{|c|}{ Healthy controls $(n=189)$} & \multicolumn{3}{|c|}{ Sporadic CJD patients $(n=180)$} & $P$-value ${ }^{3}$ & $P$-value ${ }^{4}$ \\
\hline & $\mathrm{EE}(\mathrm{n}=173)$ & EK $(n=16)$ & $K K(n=0)$ & $\mathrm{EE}(n=180)$ & $\mathrm{EK}(\mathrm{n}=0)$ & $\mathrm{KK}(\mathrm{n}=0)$ & & \\
\hline \multicolumn{9}{|c|}{ Genotype frequency, n (\%) } \\
\hline$\pi$ & $86(49.7)$ & $5(31.3)$ & - & 87 (48.3) & - & - & & \\
\hline $\mathrm{TC}$ & 68 (39.3) & $9(56.3)$ & - & $78(43.3)$ & - & - & 0.338 & 0.600 \\
\hline $\mathrm{CC}$ & $19(11.0)$ & $2(12.4)$ & - & $15(8.3)$ & - & - & & \\
\hline \multicolumn{9}{|c|}{ Allele frequency } \\
\hline $\mathrm{T}$ & 0.69 & 0.59 & - & 0.70 & - & - & 0.244 & 0.854 \\
\hline C & 0.31 & 0.41 & - & 0.30 & - & - & & \\
\hline
\end{tabular}

${ }^{1}$ Difference in healthy controls with MM and healthy controls with MV.

${ }^{2}$ Difference in healthy controls with MM and sporadic CJD patients with MM.

${ }^{3}$ Difference in healthy controls with EE and healthy controls with EK.

${ }^{4}$ Difference in healthy controls with EE and sporadic CJD patients with EK. 
sporadic CJD shows a susceptibility effect at codon 129 and 219 on PRNP in Koreans [4]. The PRNP polymorphism at codon 219 is unique to Asian populations, and PRNP 219EK heterozygous genotype has a protective effect on sporadic CJD development [4]. In analysis stratified by PRNP codon 129 or 219 status, we found no significant difference in the genotype and allele frequencies of RPSA 5'-UTR -8T>C polymorphism according to the PRNP codon 129 or 219 status (Table 6). These results are a function of the fact that all sporadic CJD patients had only PRNP 129MM or 219EE genotype.

\section{Conclusions}

Although RPSA alone is not a disease-modifying gene for sporadic CJD in Koreans, these SNPs might have an effect on the expression or susceptibility of RPSA gene and $\operatorname{PrP} \mathrm{C}^{\mathrm{C}}$-LRP-LR interaction. In this case-control study, we included only Korean populations; therefore this result may not be generalized to other ethnicities. There are comparatively few Koreans diagnosed with sporadic CJD; this contributes to the limitation of the power analysis. Nevertheless, this study is important in that it forms the foundation of genetic association study on RPSA gene and sporadic CJD. Further genetic studies on whether variants in RPSA gene are associated with human prion disease should examine various ethnicities and larger numbers.

\section{Acknowledgements}

This study was supported by a grant of the Korea Healthcare technology R\&D Project, Ministry of Health \& Welfare, Republic of Korea (A085082).

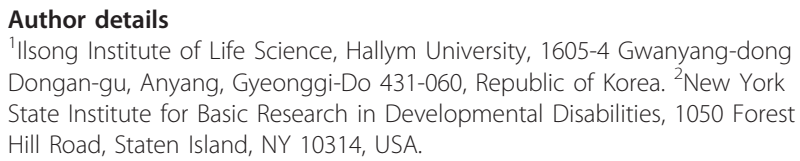

\section{Authors' contributions}

$J Y, B H J$, and YSK designed the study. JY, HTJ, and YJL performed the genotyping. JY, EKC, RIC, BHJ, and YSK analyzed the data. JY and BHJ performed statistical analysis. JY, RIC, BHJ, and YSK wrote the paper. All authors read and approved the final manuscript.

\section{Competing interests}

The authors declare that they have no competing interests.

Received: 30 March 2011 Accepted: 13 August 2011 Published: 13 August 2011

\section{References}

1. Prusiner SB: Molecular biology of prion disease. Science 1991, 252:1515-1522.

2. Aguzzi A, Calella AM: Prions: protein aggregation and infectious diseases. Physiol Rev 2009, 89:1105-1152.

3. Alperovitch A, Zerr I, Pocchiari M, Mitrova E, de Pedro Cuesta J, Hegyi I, Collins S, Kretzschmar H, van Duijn C, Will RG: Codon 129 prion protein genotype and sporadic Creutzfeldt-Jakob disease. Lancet 1999, 353:1673-1674

4. Jeong BH, Lee KH, Kim NH, Jin JK, Kim Jl, Carp Rl, Kim YS: Association of sporadic Creutzfeldt-Jakob disease with homozygous genotypes at
PRNP codons 129 and 219 in the Korean population. Neurogenetics 2005, 6:229-232.

5. Jeong BH, Nam JH, Lee YJ, Lee KH, Jang MK, Carp Rl, Lee HD, Ju YR, Ahn Jo S, Park KY, Kim YS: Polymorphisms of the prion protein gene (PRNP) in a Korean population. J Hum Genet 2004, 49:319-324.

6. Carp Rl, Meeker H, Sersen E, Kozlowski P: Analysis of the incubation periods, induction of obesity and histopathological changes in senescence-prone and senescence-resistant mice infected with various scrapie strains. J Gen Virol 1998, 79:2863-2869.

7. Lloyd SE, Onwuazor ON, Beck JA, Mallinson G, Farrall M, Targonski P, Collinge J, Fisher EM: Identification of multiple quantitative trait loci linked to prion disease incubation period in mice. Proc Natl Acad Sci USA 2001, 98:6279-6283.

8. Stephenson DA, Chiotti K, Ebeling C, Groth D, DeArmond SJ, Prusiner SB, Carlson GA: Quantitative trait loci affecting prion incubation time in mice. Genetics 2000, 69:47-53.

9. Moreno CR, Cosseddu GM, Schibler L, Roig A, Moazami-Goudarzi K, Andreoletti O, Eychenne F, Lajous D, Schelcher F, Cribiu EP, Laurent P, Vaiman D, Elsen JM: Identification of new quantitative trait Loci (other than the PRNP gene) modulating the scrapie incubation period in sheep. Genetics 2008, 179:723-726.

10. Qiao J, Su X, Wang Y, Yang J, Kouadir M, Zhou X, Yin X, Zhao D: Cloning and characterization of full-length coding sequence (CDS) of the ovine 37/67-kDa laminin receptor (RPSA). Mol Biol Rep 2009, 36:2131-2137.

11. Nelson J, McFerran NV, Pivato G, Chambers E, Doherty C, Steele D, Timson DJ: The $67 \mathrm{kDa}$ laminin receptor: structure, function and role in disease. Biosci Rep 2008, 28:33-48.

12. Rieger $\mathrm{R}$, Lammézas $\mathrm{Cl}$, Weiss $\mathrm{S}$ : Role of the $37 \mathrm{kDa}$ laminin receptor precursor in the life cycle of prions. Transfus Clin Bil 1999, 6:7-16

13. Gauczynski S, Peyrin JM, Haïk S, Leucht $C$, Hundt C, Rieger R, Krasemann $S$, Deslys JP, Dormont D, Lasmézas Cl, Weiss S: The 37-kDa/67-kDa laminin receptor acts as the cell-surface receptor for the cellular prion protein. EMBO J 2001, 20:5863-5875.

14. Gauczynski S, Nikles D, El-Gogo S, Papy-Garcia D, Rey C, Alban S, Barritault D, Lasmezas Cl, Weiss S: The 37-kDa/67-kDa laminin receptor acts as a receptor for infectious prions and is inhibited by polysulfated glycanes. J Infect Dis 2006, 194:702-709.

15. Rieger $\mathrm{R}$, Edenhofer F, Lasmézas $\mathrm{Cl}$, Weiss S: The human 37-kDa laminin receptor precursor interacts with the prion protein in eukaryotic cells. Nat Med 1997, 3:1383-1388

16. Morel E, Andrieu T, Casagrande F, Gauczynski S, Weiss S, Grassi J, Rousset M, Dormont $\mathrm{D}$, Chambaz J: Bovine prion is endocytosed by human enterocytes via the $37 \mathrm{kDa} / 67 \mathrm{kDa}$ laminin receptor. Am J Pathol 2005, 167:1033-1042.

17. Leucht C, Simoneau S, Rey C, Vana K, Rieger R, Lasmézas Cl, Weiss S: The $37 \mathrm{kDa} / 67 \mathrm{kDa}$ laminin receptor is required for $\operatorname{PrP}(\mathrm{Sc})$ propagation in scrapie-infected neuronal cells. EMBO Rep 2003, 4:290-295.

18. Qiao JW, Su XO, Li YX, Yang JM, Wang YQ, Kouadir M, Zhou XM, Yang LF, Yin $\mathrm{XM}$, Zhao DM: Variable levels of $37-\mathrm{kDa} / 67-\mathrm{kDa}$ laminin receptor (RPSA) mRNA in ovine tissues: potential contribution to the regulatory processes of PrPSc propagation? Anim Biotechnol 2009, 20:151-155.

19. Zuber C, Mitteregger G, Schuhmann N, Rey C, Knackmuss S, Rupprecht W: Reusch U, Pace C, Little M, Kretzschmar HA, Hallek M, Büning H, Weiss S: Delivery of single-chain antibodies (scFvs) directed against the 37/67 $\mathrm{kDa}$ laminin receptor into mice via recombinant adeno-associated viral vectors for prion disease gene therapy. J Gen Virol 2008, 89:2055-61.

20. Vana K, Zuber C, Pflanz H, Kolodziejczak D, Zemora G, Bergmann AK, Weiss S: LRP/LR as an alternative promising target in therapy of prion diseases, Alzheimer's disease and cancer. Infect Disord Drug Targets 2009 9:69-80.

21. Pflanz H, Vana K, Mitteregger G, Pace C, Messow D, Sedlaczek C, Nikles D, Kretzschmar HA, Weiss SF: Microinjection of lentiviral vectors expressing small interfering RNAs directed against laminin receptor precursor mRNA prolongs the pre-clinical phase in scrapie-infected mice. J Gen virol 2009, 90:269-274.

22. Pflanz $H$, Vana $K$, Mitteregger $G$, Renner-Müller I, Pace C, Küchenhoff $H$, Kretzschmar HA, Wolf E, Weiss S: Scrapie-infected transgenic mice expressing a laminin receptor decoy mutant reveal a prolonged incubation time associated with low levels of PrPres. J Mol Biol 2009, 388:721-729 
23. Fujimura $\mathrm{Y}$, Umeda D, Yamada $\mathrm{K}$, Tachibana $\mathrm{H}$ : The impact of the $67 \mathrm{kDa}$ laminin receptor on both cell-surface binding and anti-allergic action of tea catechins. Arch Biochem Biophys 2008, 476:133-138.

24. Ku HC, Chang HH, Liu HC, Hsiao CH, Lee MJ, Hu YJ, Hung PF, Liu CW, Kao $\mathrm{YH}$ : Green tea (-)-epigallocatechin gallate inhibits insulin stimulation of 3T3-L1 preadipocyte mitogenesis via the 67-kDa laminin receptor pathway. Am J Physiol Cell Physiol 2009, 297:C121-132.

25. Umeda D, Yano S, Yamada K, Tachibana H: Green tea polyphenol epigallocatechin-3-gallate signaling pathway through 67-kDa laminin receptor. J Biol Chem 2008, 283:3050-3058.

26. Rambold AS, Miesbauer M, Olschewski D, Seidel R, Riemer C, Smale L, Brumm L, Levy M, Gazit E, Oesterhelt D, Baier M, Becker CF, Engelhard M, Winklhofer KF, Tatzelt J: Green tea extracts interfere with the stressprotective activity of $\mathrm{PrP}^{\mathrm{C}}$ and the formation of $\mathrm{PrP}^{\mathrm{Sc}}$. J Neurochem 2008, 107:218-229.

27. World Health Organization: Creutzfeldt-Jakob disease (CJD) and variant CJD (vCJF), excerpt from WHO recommended standards and strategies for surveillance, prevention and control of communicable diseases. [cited 2010 Dec 13]. [http://www.who.int/entity/zoonoses/diseases/ Creutzfeldt.pdf].

28. Hundt C, Peyrin JM, Haïk S, Gauczynski S, Leucht C, Rieger R, Riley ML, Deslys JP, Dormont D, Lasmézas Cl, Weiss S: Identification of interaction domains of the prion protein with its $37-\mathrm{kDA} / 67-\mathrm{kDa}$ laminin receptor. EMBO J 2001, 20:5876-5886.

29. Kazmin DA, Hoyt TR, Taubner L, Teintze M, Starkey JR: Phage display mapping for peptide 11 sensitive sequences binding to laminin-1. J Mol Biol 2000, 298:431-445.

30. Marcos-Carcavilla A, Calvo JH, González C, Serrano C, Moazami-Goudarzi K, Laurent $P$, Bertaud M, Hayes H, Beattie AE, Lyahyai J, Martín-Burriel I, Torres JM, Serrano M: Structural and functional analysis of the ovine laminin receptor gene (RPSA): Possible involvement of the LRP/LR protein in scrapie response. Mamm Genome 2008, 19:92-105.

31. Zhou R, Li X, Zheng H, Li L, Quan W, Shen Z, Tong J, Yang Q, Fu Q: Molecular Characterization of the Full-Length Coding Sequence of the Caprine Laminin Receptor Gene (RPSA). Biochem Genet 2010, 48:962-969.

32. Baloui H, von Boxberg Y, Vinh J, Weiss S, Rossier J, Nothias F, Stettler O: Cellular prion protein/laminin receptor: distribution in adult central nervous system and characterization of an isoform associated with a subtype of cortical neurons. Eur J Neurosci 2004, 20:2605-2616.

33. Belichenko PV, Miklossy J, Belser B, Budka H, Celio MR: Early destruction of the extracellular matrix around parvalbumin-immunoreactive interneurons in Creutzfeldt-Jakob disease. Neurobiol Dis 1999, 6:269-279.

\section{Pre-publication history}

The pre-publication history for this paper can be accessed here: http://www.biomedcentral.com/1471-2350/12/108/prepub

doi:10.1186/1471-2350-12-108

Cite this article as: Yun et al:: The first report of RPSA polymorphisms, also called 37/67 kDa LRP/LR gene, in sporadic Creutzfeldt-Jakob disease (CJD). BMC Medical Genetics 2011 12:108.

\section{Submit your next manuscript to BioMed Central and take full advantage of:}

- Convenient online submission

- Thorough peer review

- No space constraints or color figure charges

- Immediate publication on acceptance

- Inclusion in PubMed, CAS, Scopus and Google Scholar

- Research which is freely available for redistribution

Submit your manuscript at www.biomedcentral.com/submit
Biomed Central 